\title{
NARRATIVAS URBANAS: \\ ACESSO À MORADIA, ORGANIZAÇÃO FAMILIAR E A (RE)PRODUÇÃo \\ DO ESPAÇO URBANO
}

\author{
Thalles Vichiato Breda ${ }^{1}$
}

\section{Introdução ${ }^{2}$}

Este trabalho apresenta resultados das imersões etnográficas realizadas entre 2017 e 2018, em um bairro periférico promovido pelo Programa Minha Casa Minha Vida (PMCMV), na cidade de São Carlos/ $\mathrm{SP}^{3}$. No contexto geral da pesquisa realizada para o mestrado, tratei das formas combinadas de produção do espaço urbano (por "baixo" e por "cima") e sua relação com as formas de gestão de determinados grupos e do ordenamento social da população pobre periférica - resultante da ação do Estado, do capital e de distintos atores sociais nas "parcerias público-privado" -, que dão sentido à vida cotidiana, especialmente na periferia pobre da cidade de São Carlos (Breda, 2018).

Inicialmente, a cidade de São Carlos chamou atenção pela elevada produção de habitação de interesse social (HIS) fomentada pelo Programa Minha Casa Minha Vida Faixa 1 (PMCMV-1): cerca de três mil unidades desde 2011, em uma cidade com aproximadamente 221.950 habitantes e 72 mil domicílios permanentes (IBGE, 2010). À parte a HIS, figuravam também, pela cidade, inúmeros outdoors de imobiliárias e construtoras expondo os vários empreendimentos em lançamento voltados para a "classe média", promovidos pela categoria de habitação de mercado (Faixas 2 e 3 do PMCMV).

Posteriormente, constatei que havia cerca de sete mil unidades habitacionais produzidas e financiadas pela Faixa 2 e 3 . A cidade de São Carlos, famosa por ser a "capital da tecnologia", com seu elevado Índice de Desenvolvimento Humano Municipal, sua suposta renda elevada, movimentada pelas duas grandes universidades a Universidade de São Paulo (USP) e a Universidade Federal de São Carlos (UFSCar) -

\footnotetext{
${ }^{1}$ Universidade Federal de São Carlos, Brasil. Email: thallesvbreda@gmail.com ORCID id: https://orcid.org/0000-0001-5584-3003

${ }^{2}$ Este artigo é fruto dos resultados obtidos na dissertação intitulada "Articulações entre a produção do espaço urbano e a gestão do social: agentes e escalas na produção do PMCMV em São Carlos/SP" (Breda, 2018), sob orientação da Profa. Dra. Isabel Georges; e do artigo apresentado no âmbito da XIII Reunião de Antropologia do Mercosul (2019), no GT Narrativas etnográficas das e nas metrópoles contemporâneas: desafios e perspectivas.

${ }^{3}$ Localizado na porção central do estado de São Paulo, São Carlos conta com cerca de 251 mil residentes (IBGE, 2019).
} 
e um Parque Tecnológico, havia entrado no eixo de produção em massa de habitação de interesse social e de mercado, subsidiado pelo PMCMV, alterando visivelmente o tecido urbano e as sociabilidades urbanas.

No contexto global, em um primeiro momento analisei a produção dos indicadores de déficit habitacional, tanto na escala nacional, quanto em sua tradução local. Posteriormente, analisei a espacialização das unidades habitacionais e a relação com a produção do espaço urbano. Por fim, realizei, durante um ano (2017-2018), incursões etnográficas no bairro Jd. Zaváglia.

Para este artigo, privilegiei os resultados das incursões etnográficas: a agência da população, especialmente as organizações familiares, as formas de estratégia do cotidiano e as relações estabelecidas com a expansão do espaço urbano. Serão analisadas as narrativas sobre trajetórias de moradia e emprego de duas famílias residentes no bairro Jd. Zaváglia - empreendimento que conta com cerca de mil unidades habitacionais. O bairro se caracteriza pelo alto grau de segregação socioespacial, localizado no cinturão sudeste de bairros populares de São Carlos.

O artigo está organizado em três principais seções (além da Introdução e Notas Finais): Perspectivas teóricas, na qual elenco elementos teóricos sobre a produção do espaço urbano e a organização familiar dos pobres; Narrativas Urbanas, na qual discuto a trajetória de vida de Maria e como a casa própria foi fundamental para sua estabilização, e, posteriormente, discuto a trajetória do casal Roberto e Karol, elencando elementos religiosos no "ganhar" a casa e, por outro lado, o pesadelo que a casa própria se tornou; e em A Família, a casa e a cidade, discuto as trajetórias familiares e as potencialidades na produção do espaço urbano.

\section{Perspectivas teóricas: a cidade e a família}

Para compreendermos a agência da população, especialmente as organizações familiares, as formas de estratégia do cotidiano e as relações estabelecidas com a expansão do espaço urbano, partimos da perspectiva de Agier (2015: 484) de "fazercidade". Segundo o autor, a cidade é feita de movimento, das relações práticas e das narrativas que buscam caracterizá-la e moldá-la. Caracterizações estas que não são eternas e nem limitadas. Neste sentido, a reprodução do espaço urbano e suas formas de ordenamento (concretas e simbólicas) são objetos de disputas e contradições por meio 
das formas de apropriação do espaço. A produção do espaço urbano é um produto social, histórico e ao mesmo tempo imediato (Carlos, 2017).

Os agentes da produção do espaço urbano privilegiados nesta análise - as famílias populares urbanas -, são entendidos aqui de forma genérica como aqueles que são destituídos de riqueza, prestígio social e alto grau de poder (Couto, 2005). Privilegio a potencialidade da família enquanto instância ordenadora simbólica do mundo cotidiano, as formas de organização interna e sua relação com as formas externas, a divisão sexual do trabalho, a regulação da sexualidade e a construção social dos gêneros enraizados. Busca-se discutir as relações familiares entre o público e o privado, assim como leva-se em consideração a importância do lugar de residência para a organização social da família (León, 1994; Fonseca, 2004; Sarti, 1996, 2004).

A família, para os pobres, "se refere à sua identidade de ser social e constitui o parâmetro simbólico que estrutura sua experiência no mundo". E, é nisso que me interesso: como as famílias se narram, se auto organizam e dão sentido ao mundo, em uma relação dialética (Sarti, 1996: 33). No caso, sob o marco do PMCMV.

Aqui, a estrutura familiar não aparece enquanto fixa, e sim como processo. Para Sarti (1996), as relações familiares são baseadas em códigos de lealdade, e obrigações mútuas e recíprocas a partir de categorias de trabalho, moralidade e hierarquia. Para Fonseca (2004), a honra é um elemento simbólico chave para compreender as famílias populares, pois ao mesmo tempo que regula o comportamento, define a identidade dos membros do grupo. Tanto Sarti como Fonseca se recusam a olhar para a família somente como reprodutora da força de trabalho, em uma interpretação material e econômica. Esta abordagem privilegia os componentes simbólicos em detrimento dos aspectos econômicos ${ }^{4}$. Não se trata de ignorá-los, mas sim de compreender os aspectos familiares sob outro prisma - do mundo simbólico e das moralidades. O mundo do trabalho, para além da esfera econômica e material, revela questões pertinentes sobre identidades, honra, orgulho e visão de mundo (Fonseca, 2004; Sarti, 1996).

A família, para Sarti (2004), aparece como realidade simbólica, delineada por uma história contada, recontada, e ressignificada pela própria família e seus distintos membros, em momentos diferentes, levando em consideração eventos externos e internos. Como a autora sugere, é preciso pensar a família sobre o discurso de si própria, internalizada pelos sujeitos, nos permitindo compreender como a família

\footnotetext{
${ }^{4}$ Sobre abordagens familiares pelo viés mais econômico, o paradigma da produção, do capital e da reprodução da força de trabalho ver Fausto Neto (1982); Woortmann (1987) e Motta \& Scott (1983).
} 
constrói a ela mesma, a sua própria ordem simbólica, e como se relaciona com as regras da sociedade em que se vive. Como coloca a autora:

\begin{abstract}
Nesse jogo entre o mundo exterior e o mundo subjetivo, as construções simbólicas operam numa relação especular. O discurso social sobre a família se reflete nas diferentes famílias, como um espelho. Em cada caso, entretanto, há uma tradução desse discurso, que, por sua vez, devolverá ao mundo social sua imagem, filtrada pela singularidade das experiências vividas. Assim, cada família constrói seus mitos a partir do que ouve sobre si, do discurso externo internalizado, mas devolve um discurso sobre si que contém também sua própria elaboração, objetivando sua experiência subjetiva (Sarti, 2004: 14-15).
\end{abstract}

É fundamental pontuar que a formulação de família não se confunde com a unidade reprodutora biológica ou mesmo laços de sangue. O corpo, aqui, está inscrito na e pela cultura, e muitas vezes cristalizado por referenciais de famílias socialmente construídas por meio de dispositivos disciplinares. A família se define por indivíduos unidos por elos significantes que criam sentido nas relações e, sem os quais essas relações se enfraqueceriam, perdendo o sentido. A família é o filtro pelo qual se começa a ver e a significar o mundo, dando sentido às relações entre os indivíduos, e servindo de espaço para a elaboração de experiências vividas. A tensão interna à família e ao mundo externo é posta constantemente, e colabora para a construção de identidades. A família, então, constitui-se dialeticamente entre ela e o mundo externo (Fonseca, 2004; Sarti, 2004).

A discussão deste artigo se pautará sobre as formas de sociabilidade (re)produzidas no bairro, por meio da narrativa de duas famílias sobre suas origens familiares e formas de organização, os deslocamentos em busca de habitação, o papel das políticas sociais (em especial o Programa Bolsa Família e o PMCMV), e as diversas organizações de gênero. Apresento suas percepções em relação ao bairro, aos deslocamentos cotidianos, ao acesso à saúde e aos equipamentos de uso coletivo. Observam-se nestas narrativas as práticas familiares em operação para mudar a si mesmo ou o mundo à sua volta, relacionado aos contextos socioeconômicos conjunturais.

Ainda, durante estes percursos, aponto momentos históricos importantes do desenvolvimento do parcelamento e uso do solo urbano de São Carlos. Isto ajudará a compreender parte do processo de expansão da periferia sudoeste, onde se localizam os três bairros do PMCMV-1. Esta região se consolidou ao longo do século XX como lócus de moradia da classe mais pobre de São Carlos, caracterizada por loteamentos sem 
infraestrutura mínima e acesso reduzido, configurando o processo de segregação urbana (Lima, 2008). Desta forma, este artigo tem a intenção de discutir como as vivências cotidianas se relacionam com a produção do espaço urbano, suas formas de uso e apropriação do espaço pela população, entrelaçados aos processos socioeconômicos macroestruturais.

As duas famílias escolhidas para a discussão são moradoras do Jd. Zaváglia. A escolha se deu na medida em que estas famílias apresentavam uma diversidade em suas narrativas e, ao mesmo tempo, pontos de contato para podermos discutir sobre a família popular brasileira. Por outro lado, as narrativas de moradia, trabalho e arranjos familiares apresentam divergências, nos mostrando as distintas faces que uma política social pode representar nas estratégias do cotidiano. Neste sentido, buscamos explorar as "saídas" (Cabanes, 2011) apresentadas pelas famílias para compreender seu cotidiano e, por vezes, justificar as próprias decisões internas.

\section{Narrativas urbanas}

\subsection{Considerações do bairro Jd. Zaváglia}

Antes de adentrarmos às duas narrativas, gostaria de fazer alguns apontamentos sobre o bairro. O Jardim Zaváglia (ver Figura 1), inaugurado em 2011, foi o primeiro bairro do PMCMV-1 em São Carlos, e conta com mil unidades habitacionais e com uma população entre 3 a 5 mil moradores. Em relação ao padrão habitacional, o bairro é muito homogêneo. Essa homogeneidade se refere ao tamanho dos lotes e casas, quadras parecidas, ruas geometricamente planejadas, formando longos retângulos dispostos lado a lado. Rufino (2015) também constatou, a partir de uma coletânea de estudos (Amore et al., 2015), que há uma ampla padronização de projetos de grande porte para a Faixa 1, de maneira a não respeitar as diferentes realidades locais, apontando para uma racionalidade imposta pelo Programa.

Outro ponto interessante são as áreas institucionais e as áreas específicas de comércio, que criam zonas artificiais e delimitadas para tais funções. No Jd. Zaváglia, a área destinada ao uso institucional localiza-se no centro do bairro, iniciando na área onde se localiza uma $\mathrm{ONG}$, até seu prolongamento na avenida principal. A área de comércio, por outro lado, situa-se somente na última avenida, na ponta norte do bairro. 
Desta maneira, a população que mora ao sul, desprovida de veículo particular, deve caminhar por todo o bairro em busca do comércio local.

Em minhas visitas à campo foi possível observar o pequeno comércio local adaptado nas casas e quintais. De modo geral, o bairro se caracteriza pelo processo de periferização e aparente monofuncionalidade ${ }^{5}$, enquanto bairro dormitório. Porém, esta "monofuncionalidade" pode ser questionada justamente pela implementação de trabalhos e serviços em domicílios. Orsi (2020), em seu estudo sobre pós-ocupação em bairros do PMCMV-1 em Araraquara/SP, também destaca o afloramento de pequenos comércios e prestação de serviços nas casas, mudando sua função primária - de moradia.

Em torno do bairro todo há uma vegetação que o separa da malha urbana contígua e dos bairros limítrofes. Em relação aos equipamentos de uso coletivo e de consumo, o Jd. Zaváglia conta com dois playgrounds com academia ao ar livre. Há a Unidade Saúde da Família, que foi inaugurada em 2020 após um longo período onde a construção já finalizada ficou parada, chegando a abrigar uma família; há a ONG Céu $\mathrm{Azul}^{6}$, que dá suporte às crianças do bairro; e a Escola Estadual Jardim Zaváglia, inaugurada em 2016. Nota-se que a chegada, no bairro, de alguns equipamentos públicos básicos demoraram entre 5 e 10 anos.

A região onde o bairro se localiza é caracterizada pela segregação socioespacial, pela baixa renda de seus moradores e pelo predomínio de população preta e parda (Breda, 2018). Tal característica dos bairros de habitação social não é exclusiva do Jd. Zaváglia ou de São Carlos. Orsi (2018) demonstrou que os bairros do PMCMV- Faixa 1 em Araraquara/SP seguem as mesmas características: concentração de famílias com baixa renda, concentração de pretos e pardos e uma taxa de analfabetismo relativamente alta, somadas à distância da região central da cidade, revelando uma fragmentação do tecido urbano da cidade.

Em Ribeirão Preto a dinâmica também se repete, como demonstrado por Barcella (2019). Na cidade, os empreendimentos Faixa 1 se localizam nas periferias com menor inserção urbana, com infraestrutura precária e menor oferta de serviços. É nestas regiões, também, que se concentram um maior número de chefes de família com menores rendimentos mensais. Outra característica semelhante ao caso de São Carlos é

\footnotetext{
${ }^{5}$ Sobre a questão da aparente monufuncionalidade, ver Rizek (2012).

${ }^{6}$ Sobre o papel da ONG no bairro e sua relação com o PMCMV e o trabalho de Pós-ocupação, ver Breda (2018).
} 
o fato de que o PMCMV reforça um padrão de estruturação que já estava em processo. A região norte, onde se localizam os empreendimentos Faixa 1, em Ribeirão Preto, foi historicamente fomentada pela $\mathrm{COHAB}$, majoritariamente. Em São Carlos, a região sul, onde se localizam os empreendimentos Faixa 1, também foi historicamente fomentada por programas de assistência e habitação social, majoritariamente (Breda, 2018; Barcella, 2019).

Figura 1: Bairros e locais citados nas narrativas familiares, São Carlos.

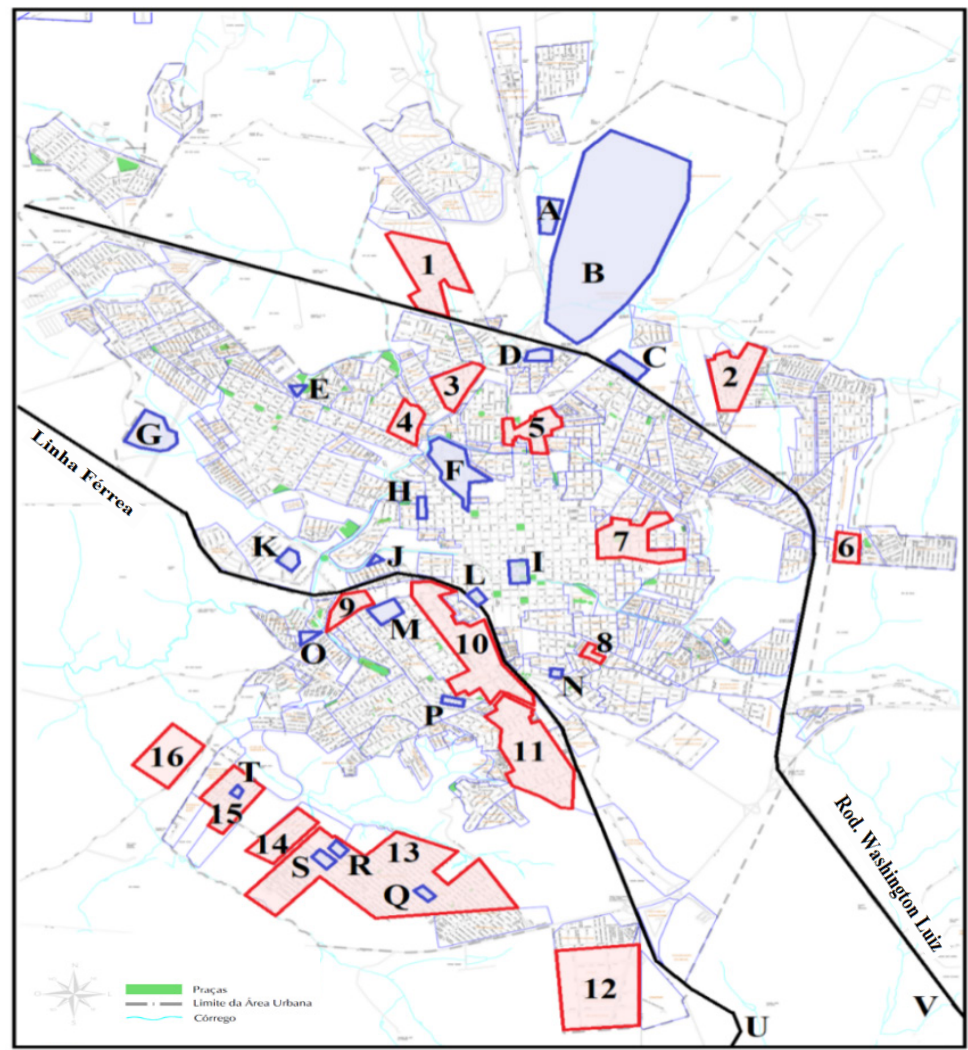

Fonte: Breda, 2018. Dados: Mapa Prefeitura Municipal de São Carlos, 2013.

\section{LEGENDA:}

\section{$\triangle$ BAIRROS:}

1. Jóquei Clube

2. São Carlos VIII

3. Jd. Paulistano

4. Santa Paula

5. Tijuco Preto

6. Jd. Tangará

7. Vila Nery

8. Vila Marcelina

\section{Botafogo}

10. Vila Prado

11. Cruzeiro do Sul

12. CEAT

13. Cidade Aracy

14. Antenor Garcia

15. Jd. Zaváglia

16. Ed. Abdelnur $\triangle$ LOCAIS:
A. ABASC
B. UFSCar
C. BR Frangos
D. Hospital Escola
E. UPA St. Felícia
F. USP Campus I
G. USP Campus II
H. Santa Casa
I. Catedral/Centro
J. SESC
K. Shopping Iguatemi
L. Estação Ferroviária
M. Electrolux
N. Centro Médico Municipal
O. UBS Botafogo
P. UPA Vila Prado
Q. UPA Cidade Aracy
R. E.M. Arthur Derigge
S. Pista de Skate/ E.E. Cidade
Aracy
T. USF Jd. Zaváglia 
Os casos se repetem de modo semelhante. Em São José do Rio Preto foram implementados grandes empreendimentos padronizados de baixa qualidade construtiva, distantes do centro consolidado, com precariedades urbanísticas, e concentrando uma população com baixa renda, como aponta o estudo de Siqueira (2015).

Bairros com estas características revelam um processo de novas fronteiras de expansão que se inauguram para além das antigas periferias, originando em "frentes pioneiras", valorizando os lotes intermediários e separando os novos da malha consolidada, assim modificando dinâmicas das sociabilidades urbanas.

\subsection{Os programas sociais e a estabilidade familiar - Maria.}

A casa de Maria ${ }^{7}$, como a chamo, é cercada por um muro sem reboco, e por um portão comprado em um ferro velho, e em seu quintal existe apenas um pouco de mato e terra. A casa não apresentava nenhuma modificação estrutural, apenas o desgaste do tempo. Maria me recebeu e concedeu a entrevista na sala. Sentei-me de frente à ela em um sofá de dois lugares, bem gasto, enquanto ela ocupava o outro sofá, nas mesmas condições. Estávamos sozinhos. Pude observar toda a sua sala, equipada com uma TV de tubo de 29 polegadas, um rack e os dois sofás. Do lugar que estava, era possível notar as duas portas dos quartos, a porta entreaberta do banheiro azulejado, e a cozinha. Maria vestia shorts preto desbotado, uma camiseta cavada com manchas e alguns furos, e, no pé, um chinelo gasto.

\section{Narrativa da trajetória:}

Maria, 38 anos (1978), negra, divorciada, dois filhos (um de onze anos e uma de oito anos)), moradora da periferia, trabalhadora do ramo da faxina, chefe de família. Nasceu no Piaú e compunha uma família numerosa, com oito irmãos e irmãs e sua mãe, divorciada. Embora Maria não date com precisão quando ela e sua família migraram para São Carlos, consegue se lembrar de que aos 12 ou 13 anos já estendia os ofícios aprendidos no universo familiar para o universo do trabalho, realizando serviços de babá, faxineira, ou "dando uma mão nisso ou naquilo" para os conhecidos da sua mãe ou familiares, em São Carlos. Deste modo, sua família teria migrado em algum momento da década de 1980.

\footnotetext{
${ }^{7}$ Entrevista realizada em 17 de março de 2017, com duração de uma hora e quarenta e cinco minutos.
} 
Quando sua família chegou a São Carlos, foram morar de favor em uma casa cedida de uma família de classe média. Este contato foi intermediado pela rede de amigos que migraram junto com eles. Com o tempo, seus irmãos foram arrumando emprego e se mudando, ficando apenas ela e a mãe, de modo que, eventualmente, se mudaram juntas. Durante este período, até o falecimento de sua mãe em 1999, Maria completou os seus estudos no colegial junto com a formação de Técnico em Computação. Quando sua mãe adoeceu e seus irmãos já não moravam mais com elas, sozinha assumiu os cuidados da mãe e as contas da casa, sendo obrigada a abandonar qualquer possibilidade de estudo superior, e começou a trabalhar em dois empregos para manter a casa. Maria ressalta que foi por volta de seus 17 anos (1995) que assumiu as contas enquanto trabalhava na função de empregada doméstica, destacando um emprego de quase seis anos sem registro, dentre outros mais temporários, no ramo da faxina. Ela e sua mãe moraram em uma casa alugada, na Vila Nery ${ }^{8}$. Perto de sua mãe falecer, devido a uma doença de longa data, mudaram-se para o Jd. Paulistano ${ }^{9}$, em uma edícula cedida nos fundos da casa do seu cunhado.

Após o falecimento de sua mãe (1999), Maria se mudou com a irmã por um tempo e depois sentiu a necessidade de morar sozinha. Pela primeira vez, aos 21 anos aproximadamente, trabalhava e tinha sua própria casa, pagando aluguel - relata com orgulho. Durante este período, ela morou no Jóquei Clube e Cruzeiro do $\mathrm{Sul}^{10}$, e trabalhava de faxineira para um professor universitário - emprego que duraria aproximadamente três anos. Maria relata que entrou no ramo da faxina trabalhando para

\footnotetext{
${ }^{8}$ A Vila Nery foi o primeiro loteamento implementado em São Carlos (1889) que não correspondia à região central (1857). O bairro, historicamente, foi ocupado por pequenas fábricas e artesãos que davam suporte e/ou manutenção à ferrovia, que se instalou em São Carlos em 1884. Inicialmente, o centro era ocupado pela elite oligárquica cafeeira e pela incipiente classe comerciante (Lima, 2008).

${ }^{9}$ O Jd. Paulistano foi loteado em 1957, reflexo do grande processo de urbanização que passava o Brasil e, também, São Carlos, devido ao impulso da industrialização e das grandes correntes migratórias. A década de 1950, para São Carlos, marcou um grande processo de urbanização, dobrando o tamanho da área urbana e consolidando o anel periférico em volta do centro. Durante o período de 1929 a 1959, em São Carlos, houve uma expansão periférica que privilegiou os especuladores imobiliários que não provinham infraestrutura mínima para os bairros mais carentes. Neste mesmo momento as regiões sul e sudeste começam a ser dominadas pela população mais carente. Na década de 1940, em São Carlos, inicia-se o problema habitacional, uma vez que a população rapidamente torna-se majoritariamente urbana e, assim, promoveram-se múltiplos loteamentos populares precários e a autoconstrução como estratégia (Lima, 2008).

${ }^{10}$ O Jóquei Clube data de 1955 e o Cruzeiro do Sul de 1954, ambos inseridos na lógica de loteamentos populares precários, sem infraestrutura mínima. Ambos os loteamentos se caracterizam pela moradia de trabalhadores semiespecializados e não especializados. O bairro Cruzeiro do Sul marca o processo de segregação urbana, inaugurando loteamentos para além da linha férrea, na região sul, apresentando graves problemas de acessibilidade (Lima, 2008).
} 
amigas da mãe, desde criança, e, posteriormente, uma pessoa ia indicando à outra e assim ela circulava.

Aos 26 anos (2004), Maria conheceu o seu único marido e pai dos seus filhos. Um pouco antes de se casarem, em 2007, o casal morou de favor na casa da sogra (casa própria), na Vila Prado ${ }^{11}$. No mesmo ano em que se casaram, tiveram seu primeiro filho. Nestas idas e vindas, foi difícil estabelecer uma cronologia específica de sua moradia. Ela conta que já se inscrevia em programas habitacionais pela PROHAB ${ }^{12}$ desde 2008 , mas não obteve sucesso até ser chamada para atualizar o cadastro, devido ao lançamento do PMCMV. Em 2010, foi contemplada no sorteio com uma casa no Jd. Zaváglia.

Após o casamento e o nascimento do seu primeiro filho, Maria aponta que tudo ficou mais difícil em relação à moradia. Desempregada, cuidando de seu filho recémnascido e da casa, ela diz que o marido não tinha responsabilidade nenhuma de pagar o aluguel, fugindo incontáveis vezes para a casa da mãe. Assim, conta que começou a "cair neste sistema de despejo". A trajetória de moradia nos anos seguintes foi marcada por incontáveis mudanças e despejos, desde casas de aluguel até moradias cedidas. Passaram pela casa da irmã, em Ibaté ${ }^{13}$ (cidade vizinha); posteriormente pela casa do tio dele, em São Carlos; mudou-se para o Jóquei Clube novamente, onde entrou para a igreja evangélica e se batizou. Neste momento, ela consegue o auxílio do Programa Bolsa-Família, devido ao desemprego que passou por quase três anos, tendo realizado apenas poucos bicos de faxina. Como Maria relata, "foi assim: muitas casas, muitos bairros, muitos valores e também muitas pessoas que abriram as portas para a gente", tentando encontrar uma cronologia nos fatos de sua vida. O casamento de Maria parece resultar em uma dinâmica onde a mulher adquire cada vez mais responsabilidades e o cônjuge retira-se das responsabilidades.

Neste período, voltou novamente a morar em Ibaté, na casa da irmã. Em 2009, nasce sua segunda filha. Maria aponta que quando foi sorteada para o Jd. Zaváglia prometeram entregar a casa em 2010. Assim, saiu da casa da irmã e voltou para São Carlos. Chegando lá, o bairro não estava pronto, o que a fez buscar uma moradia na

\footnotetext{
${ }^{11}$ A Vila Prado, loteada em 1893, contigua à linha férrea e ao lado da estação ferroviária, foi o maior loteamento do séc. XIX, em São Carlos. Era caracterizada pela presença de operários qualificados e funcionários de qualificação média, pequenos comerciantes e pequenas fábricas (Lima, 2008).

${ }^{12}$ A Progresso e Habitação São Carlos cuida da operacionalização da política habitacional do município.

${ }^{13}$ Ibaté foi distrito do município de São Carlos até 1953.
} 
Cidade Aracy $^{14}$, onde permaneceu por um ano. Neste momento, Maria já estava divorciada (2009), embora ela pontue que mantinha uma relação com o ex-marido e só viria a romper definitivamente em 2013. Durante sua estadia na Cidade Aracy, morou de aluguel e foi despejada, passando os últimos meses aguardando a liberação da casa na sala de sua irmã, no mesmo bairro. Por influência desta, que frequentava a Igreja Vicentinos de São Paulo ${ }^{15}$, Maria começou a participar também, no mesmo bairro.

Finalmente, em 2011, Maria se mudou para a sua sonhada casa própria, com seus dois filhos e em meio a um relacionamento instável com o seu ex-marido. Neste período, contou que trabalhou registrada de faxineira em uma academia na Avenida Antônio Blanco, por quase dois anos, perdendo o direito ao Programa Bolsa-Família. Foi um dos seus poucos empregos com carteira assinada. Depois, voltou a ficar desempregada, realizando faxinas principalmente em repúblicas de estudantes.

Durante os quase dez anos de relacionamento que manteve com o seu ex-marido, Maria pontua que sempre tiveram uma relação instável, de "vai e volta" e, apesar dela ter pedido o divórcio, a separação do casal foi motivada pelo abandono dele, "ele que decidiu ir embora". Os fios que ligavam Maria ao seu marido não eram financeiros, ela sempre batalhou pelo seu salário e sua estabilidade, nunca desejando depender do marido para isso. Depois da separação definitiva, em 2013, iniciou-se uma batalha judicial ,por cerca de um ano, para o pagamento da pensão alimentícia aos filhos, que ficaram com ela.

Entre 2016 e 2017, Maria aponta para uma estabilização em sua vida devido a alguns fatores, mesmo com o desemprego. Em 2016, ganhou na justiça o direito de receber pensão do seu ex-marido. Assim, consegue colocar em dia as prestações atrasadas da casa. Somando-se a isso, no mesmo ano, começou a receber novamente o Bolsa-Família. Em 2017, Maria conseguiu um trabalho terceirizado, três vezes por semana, meio período, como auxiliar de faxineira nos Correios. Sua esperança é que seja registrada, entretanto ela relata a dificuldade do registro, uma vez que a sede da empresa fica em outra cidade e o contato entre eles é reduzido e difícil. Mesmo com essa pequena estabilização, a família de Maria vive com o mínimo. Ela destaca a dificuldade para manter a casa, comprar roupas, pagar transporte público, etc.

$* * *$

\footnotetext{
${ }^{14}$ Cidade Aracy teve loteamento aprovado na década de 1980, desenvolvendo-se durante a década de 1990. O bairro marca o início da atual periferia contemporânea na extremidade da região sul/sudoeste, em São Carlos. Sobre o processo de loteamento ilegal e expansão da Cidade Aracy, ver Poli (2004).

${ }^{15}$ Igreja de orientação católica apostólica romana.
} 
Nesta trajetória apresentada de forma resumida, observa-se que após o falecimento de sua mãe, Maria estabeleceu uma rede de ajuda familiar com as irmãs, quando o assunto foi moradia. Na questão do trabalho, ela aponta que desde pequena aprendeu os ofícios domésticos e os aplicou no universo do trabalho, passando pelos postos de babá, faxineira, diarista, mensalista e, finalmente, limpeza terceirizada. Esta trajetória não é particular de Maria. Como argumenta Sarti (1996), as filhas de famílias populares tradicionalmente crescem em torno do paradigma de se tornar dona-de-casa e, posteriormente, podem aplicar estes conhecimentos se necessitarem trabalhar fora de casa. Os trabalhos de Maria majoritariamente foram sem registro, condição comum às populações da periferia pobre (Guimarães; Georges, 2009).

Como ela destaca, sempre foi a chefe de família ${ }^{16}$ quando o assunto era gerir e pagar as contas da casa. Maria conta, com alívio, que ter sua casa própria tirou o medo de ser despejada a qualquer momento, sensação esta que foi presente durante muito tempo em sua vida, principalmente quando começou um relacionamento no qual o marido não assumia responsabilidades e ela tinha que cuidar da casa, dos filhos e procurar emprego.

Os bairros nos quais morou sempre foram afastados do centro e dos trabalhos que arrumava, "nunca trabalhei perto de casa, sempre foi essa vida de lugares longe. Perder mais tempo no ônibus do que no trabalho". Embora "acostumada" com esta dinâmica, ela frisa que o Jd. Zaváglia é o bairro mais longe que já morou em relação ao centro urbano consolidado, não fazendo contiguidade com nenhum outro bairro. Todo seu deslocamento é realizado a pé, com caronas de vizinhos (quando possível) e, sua última opção, ônibus, pois diz ser muito ruim e caro. Sobre o processo de expansão periférica de São Carlos, é possível notar que Maria e sua família passaram por bairros que compõem o anel de expansão periférico que vem se constituindo desde a década de 1940, quando se inaugurou no município os loteamentos populares precários, e quando a autoconstrução tornou-se uma estratégia.

Os programas sociais do governo federal do PT (Partido dos Trabalhadores) são muito presentes na trajetória de Maria, tanto o PMCMV, quanto o Bolsa-Família ${ }^{17}$. Ela

\footnotetext{
${ }^{16}$ Sobre a discussão do conceito de mulher chefe de família, unidade mãe-filhos, sistema matrifocal, ver Fonseca (2004).

${ }^{17}$ É importante pontuar que as origens do Programa Bolsa Família são um objeto de disputa entre os governos federais do FHC (PSDB) e do Lula (PT). Anterior ao Bolsa-Família, instituído no governo do PT, havia uma série de programas sociais focalizados voltados para o combate à pobreza, fomentados pelo governo de Fernando Henrique. O Programa Bolsa-Família, nesta perspectiva, representou a
} 
conta que atualmente o próprio programa Bolsa-Família é utilizado para pagar parte da prestação da casa, junto com a pensão do ex-marido. Ainda assim, quando se mudou para o Jd. Zaváglia, foi beneficiária do Programa Minha Casa Melhor, por meio do qual equipou sua casa com diversos móveis e aparelhos eletroeletrônicos. Infelizmente, logo depois, entraram em sua casa e roubaram praticamente tudo. Relata que quando o bairro foi inaugurado, era comum a prática de roubos em casas, principalmente porque a maioria ainda não era murada, assim como a dela.

A construção do muro da casa de Maria teve ajuda da sua antiga igreja, os Vicentinos de São Paulo. Sua irmã e seu sobrinho, que continuaram frequentando a igreja, intermediaram com o pastor para que ele fornecesse mão de obra e material para construir o muro da frente de sua casa (os outros muros, os vizinhos limítrofes construíram por conta própria). Maria tem a sensação de que os assaltos diminuíram, contudo, ela frisa insistentemente como a rua é um lugar de muita violência, brigas, facadas, tanto da população adolescente, quanto de mais velhos.

Apesar da vida difícil, dos percursos inesperados e do fim do casamento, o tom adotado por Maria ao longo da entrevista é de alguém que tenta fazer o melhor com as condições presentes e que sempre buscou ser independente - das pessoas e do governo. Corre atrás das suas coisas e não espera nada de ninguém. A “ajuda” que vem, seja pelos programas sociais ou pela pensão do marido, é recebida em bom grado, mas, aparentemente, não é entendida enquanto direito. Ela parece não se incomodar com o que recebe, mas se incomoda quando tem que pedir. A sua saída ideal para a situação da pobreza seria o trabalho, como relata:

\begin{abstract}
Maria: eles [os Vicentinos] deram uma cesta básica para a gente, mas tipo assim, eu não fico pedindo, não. A pastora tinha perguntado se eu me incomodava. Eu não me importo. Se você falar pra mim, "ah, você se importa de ganhar uma cesta básica?". Eu não me incomodo, mas eu não vou ficar pedindo, entendeu? "Ah, me dá uma cesta básica?". Não vou ficar pedindo. Eu estou tentando, batalhando por um trabalho.
\end{abstract}

É desta maneira que Maria parece conceber suas ações no mundo, não gostando de depender de ninguém. Desde muito cedo já era provedora da sua mãe. Ela reitera que "a vida é sofrida, cada um corre atrás do seu". Não parece esperar nenhuma outra melhora em sua vida que não seja pelo seu próprio esforço.

sistematização de diversos programas sociais anteriores em um só. Sobre este assunto, ver Georges e Ceballos (2014). 
Essa lógica pode ser compreendida pela lógica da moral do pobre, como argumenta Sarti (1996), onde a privação de emprego é mais do que uma privação do consumo ou de bens materiais. A condição do desemprego retira a dignidade do indivíduo. Por outro lado, a condição de emprego traduz o esforço e a competência. Não se trata apenas de ter dinheiro dentro de casa, mas também da forma como ele é conquistado. Sarti, por meio da chave analítica da dádiva - dar, receber e retribuir -, demonstra que ganhar dinheiro "sem se esforçar" não aciona a dignidade, mas pode aproximar a identidade do pobre a de um mendigo ou vadio. Podemos estender essa lógica aos programas de transferência de renda (mais populares depois dos anos 2000), através dos quais receber dinheiro sem ter contribuído para a sociedade - diferente do seguro desemprego - pode parecer desonroso, ou coisa de vagabundo. Desta forma, estar trabalhando é a melhor saída para acionar a categoria de esforço e merecimento, em troca da força de trabalho despendida.

Ainda, é interessante perceber que na questão relativa ao gênero. Mesmo sendo a provedora principal de sua família, Maria estabeleceu uma relação de dependência com o seu ex-marido. Durante dez anos se encontrou em uma relação que sempre a colocava em apuros financeiros ou de moradia, e, mesmo assim, persistiu por um tempo, mesmo depois do divórcio. A separação definitiva somente ocorreu quando ele decidiu ir embora. O mesmo tom de melancolia que relata o abandono definitivo do ex-marido é também o mesmo tom de alívio. Como que por algum motivo não tivesse a coragem de romper o relacionamento, mas desejava o seu fim. Hoje, se diz feliz sem nenhum companheiro e sem pretensões para o futuro. $\mathrm{O}$ abandono de seu ex-marido significou a cessação de qualquer possibilidade de participação dele na criação dos filhos, mesmo que precariamente, com exceção da pensão.

Fonseca (2014) nos ajuda a compreender os motivos que levaram Maria a manter um relacionamento tanto quanto instável com seu ex-marido. Para a autora, dentro da divisão sexual familiar "tradicional"18, o papel do homem não se limita em

\footnotetext{
${ }^{18}$ Para Fonseca (2004), é preciso relativizar o termo hierarquias sexuais tradicional, pois mesmo que o "patriarcalismo" tivesse comprovada influência nas classes altas, as classes trabalhadoras sempre retraduziram a moralidade oficial. Neste sentido, argumenta a autora, as mulheres das classes trabalhadoras puderam gozar de uma certa autonomia frente às classes dominantes. Outra crítica fundamental ao se falar de papéis tradicionais é que se coloca sempre as classes populares em relação às classes dominantes, como se estas última fossem detentoras da normalidade. Portanto, é preciso reconhecer outras práticas conjugais que fogem ao modelo "tradicional" e não apenas uma transferência mecânica entre as hierarquias sexuais das classes sociais. Como demonstrado por Fonseca, por meio de estudos de terceiros, os primeiros censos de Minas Gerais e São Paulo, datados do início do século XIX revelam que $40 \%$ das famílias tinham mulheres-chefe de família.
} 
trazer dinheiro para dentro de casa, mas ele pode representar uma segurança para a família, tanto na proteção da casa como na proteção da honra da mulher e das filhas. Outro ponto crucial é que o matrimônio (especialmente o primeiro casamento) tem um papel moral fundamental para a mulher, constituindo-se muitas vezes no seu objetivo de "melhorar de vida" ao um núcleo familiar. O fim do casamento pode significar o fim de um projeto de vida. Neste contexto, podemos compreender a dificuldade de Maria em se separar. Por outro lado, como lembra Fonseca, a mulher também pode acionar mecanismos estigmatizantes, por meio da fofoca, sublinhando o quanto seu ex-marido era infame, vagabundo e o quanto ela foi batalhadora - visando dar um sentido positivo à separação.

Por fim, Maria, assim como tantas outras Marias, negras, da periferia, que constituem família monoparental, parece ter pago, infelizmente, um alto preço pela sua "autonomia": a acumulação de todas as tarefas domésticas, familiares e econômicas.

\subsection{O "pesadelo" da casa própria: Roberto e Karol}

A entrevista ${ }^{19}$ realizada com Roberto e Karol se mostrou oportuna na medida em que faz um contraponto à primeira entrevista, principalmente nas questões de gênero e sobre o papel das políticas sociais na estruturação e estabilidade familiar. Nesta entrevista vamos observar, de outra maneira, o papel que uma moradia pode significar para a família, e como as políticas sociais se relacionam com o contexto de desemprego e pobreza.

Era uma manhã de quarta-feira, fui de ônibus ao Jd. Zaváglia para realizar a entrevista com o casal Roberto e Karol. Subi a rua procurando a moradia. Predominantemente as casas daquela rua eram muradas, umas com melhores acabamentos que as outras, quase todas com calçadas cimentadas e arborizadas. Vou de encontro a eles, me convidam a entrar. A casa é de esquina, cercada com um muro rebocado e um portão provavelmente adquirido em ferro-velho. No quintal, uma moto e um Tipo (modelo de carro), ambos com aspecto de velhos. Três cachorros latem em meio a materiais entulhados. Convidam-me a entrar na casa, se mostram simpáticos e receptivos.

$\mathrm{Na}$ sala, dois sofás velhos, um rack desgastado e uma TV antiga de 14 polegadas, uma estante e objetos acumulados pelos cantos. A aparência da sala e dos

\footnotetext{
${ }^{19}$ Entrevista realizada em maio de 2017, que teve a duração de duas horas e dez minutos.
} 
móveis, no geral, pareceu-me bem desgastada. Ambos vestiam roupas com aspecto de velhas. Ela, com shorts curto e uma camiseta regata, ele, com shorts e uma camiseta, ambos de chinelo. A entrevista ocorreu de modo descontraído, entre um cigarro e outro que Roberto fumava. Em certos momentos, parecia que Karol não estava apenas contando sua história, estava desabafando os momentos difíceis que sua família passou naqueles últimos dois anos: a pobreza, o desemprego, e a fome.

\section{Narrativa da trajetórias:}

Karol, 32 anos (1985), branca, casada, mãe de Laura (9), cursa supletivo da $5^{\mathrm{a}}$ e $6^{\mathrm{a}}$ série no período noturno, no bairro Cidade Aracy. Atualmente desempregada, costuma fazer bicos na área de faxina, vendedora, na roça, e "no que aparecer". Karol é filha de camponeses paranaenses que migraram em meados de 1980 para São Carlos.

Segundo ela, a família migrou para "poder melhorar de vida", uma vez que seu avô tinha uma pequena roça onde plantava e colhia para sustentar a família, mas "tinham muita dificuldade". Em primeiro, vieram seus pais, depois, migraram os avós e os tios. Embora existam parentes no Paraná ainda, Karol diz que o núcleo familiar todo migrou para São Carlos. Chegando lá, moraram de aluguel até conseguir um terreno próprio na Cidade Aracy, aproximadamente em 1990. O terreno de sua mãe foi adquirido por meio de doação, fazendo parte de um processo de expansão e especulação imobiliária que envolveu práticas ilegais de loteamento realizados conscientemente pelo loteador (Poli, 2004). "Logo quando doaram os terrenos da Cidade Aracy, quando o Airton Garcia doou, a gente já pegou, né.”, conta ela. Posteriormente, sua família construiu dois cômodos, um banheiro e uma garagem, onde passaria a morar parte da família, como ela, seu irmão, a tia e os avós. Atualmente sua mãe mora com o atual marido nesta casa, e seus parentes moram espalhados pelos bairros periféricos de São Carlos.

No ano de 2005, Karol conheceu seu único e atual marido e pai de Laura, Roberto. Até este momento ela morava com sua mãe, na Cidade Aracy. Em 2006, eles resolveram morar juntos e se mudaram para São Bernardo do Campo, em uma casa cedida pela amiga dela com a condição de cuidar do imóvel.

Seu marido, Roberto, 34 anos (1983), negro, segundo grau completo, pai de Laura, atualmente desempregado. Sua família é toda da Grande São Paulo. Sua mãe (62), ainda solteira migrou com seus oito irmãos e pais para São Paulo, 
aproximadamente na década de 1970. Roberto conta que eles vieram de Alagoas em busca de emprego, fugindo da extrema pobreza e do sofrimento que assolava sua família. Foi na Grande São Paulo que sua mãe conheceu seu pai, na década de 1990, cuja família era de São Paulo, também de origem pobre. Os dois tiveram quatro filhos, sendo ele o caçula. Roberto morou com sua mãe até o momento em que conheceu Karol e se mudaram juntos, em 2006. Neste momento, ele trabalhava em uma metalúrgica, como auxiliar de produção, registrado.

Entre 2006 e 2007, o casal passou pela casa cedida pela amiga, em São Bernardo do Campo. Posteriormente, mudou-se para um cômodo no quintal da casa da mãe de Roberto, em Santo André, mas não deu certo "por que era muita gente no mesmo quintal". Mudam-se, então, para uma casa de dois cômodos e um banheiro, onde pagariam aluguel pela primeira vez, no Jardim Santo André (Santo André). Durante este tempo, o casal conta que chegou a morar com a irmã de Roberto, em Mauá.

Em meados de 2008, o casal volta a morar na casa da mãe de Roberto e, neste mesmo momento, se juntou a uma ocupação de um terreno no Jd. Santo André, na tentativa de adquirir o terreno ocupado ou ganhar um "auxilio aluguel" da prefeitura. $\mathrm{O}$ casal conta que foram momentos difíceis para os dois. O grupo que ocupou o terreno não era unido, "não era uma invasão organizada". Karol tinha que ir todo dia ao terreno e esperar pela assistente social, que poderia, ou não, aparecer. Roberto trabalhava na metalúrgica. Neste meio tempo, ela limpava, arrumava e cercava o pedacinho de terra pretendido. Eles não chegaram a construir nenhum tipo de habitação, nunca pernoitaram lá. Neste período, Karol estava grávida e viria dar a luz à Laura (2008), dificultando mais o seu deslocamento entre a casa da sogra e o terreno pretendido. Ainda, não podia trabalhar, pois fazia "ponto" no terreno. Soma-se a isso a dificuldade financeira de comprar material para construir um barraco e as condições "desumanas" do terreno, apontado como muito íngreme, localizado em beira de rio, com muito mato e bichos.

O desemprego de Karol, as condições ruins do terreno, a filha recém-nascida, a moradia de favor na casa da sogra - onde a família não se sentia à vontade - e a ideia de que o campo de trabalho estaria melhor no interior, como acreditava Roberto, motivaram a mudança para São Carlos. Em 2009, mudam-se para a casa da mãe de Karol, na Cidade Aracy. Para Roberto, as condições de trabalho melhoraram, principalmente pelo fato de a família de Karol indicá-lo para os empregos. Para Karol, a instabilidade continuou. 
A condição de moradia da família na casa da mãe de Karol também não era confortável. Eles dividiam a casa de dois cômodos, um banheiro e garagem, com mais oito pessoas aproximadamente: "minha mãe e seu marido, meu irmão, a mulher dele, meu tio e a mulher dele, e mais não sei quem". O casal apontou que era "terrível", "uma briga constante", sem nenhuma privacidade.

A mãe de Karol tinha o costume de abrir a casa para a realização de cultos evangélicos todas as sextas. Foi em um destes cultos que Karol conheceu um pastor que "revelou que Deus iria me dar uma chave, só que não falou que era de uma casa (...) só falou que era de um desejo que eu queria muito. E o que eu pedia muito para Deus era o nosso canto. (...) Para Deus nada é impossível.”. Foi neste momento que Karol procurou se informar melhor sobre o PMCMV, que "já tinha ouvido falar", mas não acreditava que conseguiriam. Foi por intermédio de sua fé que arriscou a se inscrever e, posteriormente, foi contemplada, mudando-se para o Jd. Zaváglia em 2011. É interessante observar que o acesso ao programa social parece ser possível somente por uma providência divina, e não como possibilidade pelo direito acessível a qualquer cidadão.

O local da escolha da casa, de esquina, foi motivado pelo terreno ser um pouco maior, o que possibilitaria a construção de algum tipo de comércio para ajudar na renda familiar, segundo Karol. Entretanto, devido à situação de desemprego, não conseguiram investir em nada. Em 2016, eles construíram o muro da casa com um financiamento de cinco mil reais da Caixa, com a mão de obra do marido e com material doado pelo tio.

Sobre a questão do trabalho, Karol destaca que majoritariamente seus trabalhos foram sem registro e muito instáveis, alternando muito de emprego, desde trabalho na roça, colhendo café, laranja, panfletagem, vendedora ambulante (em São Paulo), ajudante de gesso e faxina. Ela lembra que um dos raros empregos registrados foi de auxiliar de faxina em uma unidade da Unimed, em São Carlos, "por pouco tempo". A empresa que a contratou era terceirizada e "muito desorganizada", o que a motivou a sair. Ela acredita que a dificuldade de conseguir um emprego fixo, ou com melhores salários e estabilidade, está relacionada à sua falta de escolaridade. A maior parte de sua vida passou desempregada ou em empregos informais, relata.

Por outro lado, seu marido apresenta uma trajetória diferente, com empregos de maior duração e quase sempre com registro na carteira, caracterizando-se como principal fonte de renda da família. Antes de se mudar com Karol para São Carlos 
(2009), trabalhou por "alguns anos" numa metalúrgica como auxiliar de produção, registrado. Em São Carlos, em 2010, trabalhou por cerca de um ano em uma transportadora, localizada no bairro CEAT (Centro Empresarial de Alta Tecnologia "Dr. Emílio Fehr"), registrado. Roberto conta que, embora tivesse vale-transporte, o último ponto de ônibus perto do local de seu trabalho obrigava-o a caminhar cerca de três quilômetros para chegar à empresa.

Em 2011, já morando no Jd. Zaváglia, trabalhou em uma firma de fundição. Entretanto, como viajava muito e achava perigoso deixar a mulher e a filha em casa sozinhas, preferiu demitir-se e procurar um emprego dentro da cidade. Neste último emprego, antes de demitir-se, Roberto permaneceu por cerca de um ano com registro em carteira, e o carro da empresa o pegava em casa. Posteriormente, trabalhou por cerca de um ano de ajudante de gesseiro, em uma empresa também localizada no CEAT. Recebia vale-transporte e era registrado.

Aproximadamente em 2015, Roberto entrou como cobrador na empresa que prestava o serviço municipal de transporte público, a Athenas Paulista. Ele ficou na empresa até a mesma ter o contrato encerrado e ser trocada pela atual empresa, Suzantur, em agosto de $2016^{20}$. Roberto foi recontratado pela atual empresa, assim como a maioria dos funcionários, e depois de quatro meses foi mandando embora. Quando saiu da Athenas Paulista não recebeu sua rescisão e nenhum outro direito trabalhista, assim como também não haviam depositado o seu FGTS. Quando ele foi mandado embora da Suzantur a situação se repetiu. Ele alega que a atual empresa apenas contratou os antigos funcionários para ensinarem sobre o funcionamento e, posteriormente, foram trocando todo o quadro de funcionários, com salários menores e sem benefícios.

Roberto e diversos outros funcionários aguardam audiência coletiva da Athenas Paulista e da Suzantur, marcadas para final de 2017 e 2018, respectivamente. Processos

\footnotetext{
${ }^{20}$ Em 2014, uma ação do Ministério Público já apontava que a Athenas Paulista descumpria o contrato não poderia ser renovado. Porém, a empresa continuou circulando por mais de dois anos sem o contrato até que o caso foi levado à Justiça, que determinou a troca da empresa. Em agosto de 2016, a empresa Suzantur assumiu as linhas, em caráter emergencial. Esta também apresentou problemas em seu contrato e não pode ser renovado desde janeiro de 2017. A empresa continua circulado. Em janeiro de 2018 a prefeitura decretou intervenção no transporte coletivo e assumiu o serviço, entretanto havia um número pequeno de ônibus em sua garagem que não poderia atender todas as linhas e todos os horários. Recentemente, a Suzantur, em acordo com a Prefeitura, voltou a circular. Em relação às dívidas da Athenas Paulista, cerca de 600 ex-funcionários ainda não receberam o fundo de garantia e as verbas rescisórias, que somam cerca de 16 milhões de reais. Disponível em: https://g1.globo.com/sp/sao-carlosregiao/noticia/ex-funcionarios-da-athenas-querem-leilao-de-onibus-prefeitura-espera-25-veiculos.ghtml Acesso em: 24 abril 2018.
} 
estes que podem se estender por anos para pagar os diretos de rescisão dos trabalhadores. Atualmente, Roberto faz alguns bicos de pedreiro e de jardineiro. Ele aponta que tem que aceitar trabalhos por salários menores, uma vez que a situação está muito difícil. Os meios que o casal utiliza para buscar emprego são variáveis e vão desde a pesquisa por vagas na internet, no Facebook, até a entrega de currículos pela cidade.

O casal aponta que o ano de 2017 tem sido um dos piores momentos de suas vidas, "parece que nossa vida parou depois que mudamos para cá". Não têm dinheiro para pagar as contas de água e luz, que já somam quatro meses de atraso, ou mesmo para comprar comida e se deslocar de ônibus ou moto. Karol comenta que sua filha toma café da manhã todos os dias na $\mathrm{ONG}$, porque não tem alimentos em casa. Uma das explicações dadas por eles é de que o bairro tem muita negatividade, e que as pessoas desejam muito o mal e "cuidam muito da vida dos outros". A família é beneficiária do Bolsa-Família, mas entende que os 124 reais que recebem não dão para muita coisa, "ele seria muito útil para complementação de renda, não somente como renda", diz Karol.

A vontade do casal é de alugar a casa e voltar para São Paulo, à procura de emprego. Mas o medo de perder a casa e a moral cristã parecem ser empecilhos para tanto, uma vez que a prática de alugar ou vender a casa é proibido pelo PMCMV. Karol acredita que em São Paulo, apesar do aluguel ou da ajuda financeira que davam para as famílias que os recebiam, era mais fácil arrumar "uns trocados", vendendo bolo ou salgado em pontos de ônibus, sempre "dava para voltar com um dinheirinho para casa". Prática esta que não ocorre em São Carlos.

A trajetória do casal Roberto e Karol, e a própria trajetória de seus pais e avós, revela a migração como um projeto de melhorar de vida, como explorado por Fonseca (2004) e Durham (1978). A família de Karol migrou do Paraná, e a de Roberto, de Alagoas. Posteriormente, na condição de casal, migraram para diversas regiões dentro do estado de São Paulo, até se estabelecerem definitivamente em São Carlos. Mesmo após se estabelecerem em São Carlos com a casa própria, o desejo de migrar reacende revelando que a estratégia de migração continua sendo muito utilizada pelas classes populares no projeto de melhorar de vida. 
Durante a entrevista com o casal, o caráter religioso se mostrou muito presente em suas vidas, principalmente na fala de Karol - sua atual moradia foi anunciada pelo pastor e dada por Deus. Foi sua fé que a motivou a buscar a inscrição, "eu acreditei, porque pra gente não é tudo possível, mas se a gente quiser e Deus ajudar, a gente consegue, né.”. Posteriormente, quando diz que no bairro há muita negatividade, que as pessoas "cuidam" muito umas das vidas das outras, invoca um discurso religioso comum, segundo Cabanes (2011: 35), "o julgamento moral pessimista sobre a degradação progressiva da qualidade dos homens", “A acumulação dos erros humanos levaria ao fim do mundo”. É possível perceber essa cosmovisão do casal por meio do trecho a seguir:

Roberto: Você vê essa molecada, né, de 10, 11 anos. Menina grávida, é... Com droga no meio dos dedos, foda, meu./ Karol: Hoje em dia a gente está vivendo num mundo que... Que nem diz a bíblia, né. Acho que já está chegando próximo à volta de Deus. Tudo que tá escrito na bíblia está se acontecendo, né.

Mesclada com a lógica cristã, a crítica aos vizinhos e à população do bairro pode significar uma maneira de dizer, por contraste: “eles são ruins e nós somos os corretos"; ou "há alguns casos excepcionais, mas, de modo geral, a população e nós somos decentes/bons", explica Fonseca (2004).

É interessante observar, também, como a noção de cristão do casal é acionada. Logo quando mudaram no Jd. Zaváglia, o casal pegou em flagrante um adolescente dentro de sua casa, um de seus vizinhos. Sem pensar duas vezes, ela e o marido deram um "pião" nele:

Karol: Eu acho, assim, que segurança não tem. Quando a gente mudou aqui (...) um cara entrou aqui pra roubar. Ele só não roubou mais por que nós mesmo batemos nele. Por que nós chamamos a polícia e não resolveu bosta nenhuma. Falou que ele era "de menor" e não poderia fazer nada. Aí, nós mesmo catamos ele, demos um "pião" nele. Nunca mais ele entrou.

Embora Karol não acredite nas leis humanas, como apontou, pareceu-me também que não teve paciência para esperar pelas leis divinas, colocando em prática a sua própria justiça. A crença de Karol pode se assemelhar à corrente da igreja que sua família frequentava, a Avivamento Cordeiro de Deus, de direcionamento evangélico pentecostal. Esta corrente cristã tem inclinação aos ensinamentos do Velho Testamento, onde a figura de Deus adquire um tom mais agressivo e vingativo, opondo-se à figura do Novo Testamento, de perdão e amor ao próximo. Desta forma, observamos as diversas faces que a "religião" adquire nas formas de ordenamento cotidiano, muitas 
vezes em oposição às leis estatais. Há de se pontuar que a doutrina evangélica não é uniforme, tanto no Antigo, quanto no Novo Testamento.

Ao final da entrevista, Karol volta a reiterar sua cosmovisão cristã, "Eu não tenho amor em bens materiais, eu tenho amor no próximo, no ser humano.". Suas ações são guiadas por Deus e por sua fé, "Por que eu acho assim, as pessoas têm que pensar que o sol brilha para todos, basta você correr atrás dos seus objetivos. Por que do mesmo jeito que eu consegui, você também vai conseguir".

Nota-se que há uma variedade de ações pelas quais Karol concebe o "ser cristã", recorrendo ao que Cabanes (2011) chamou de "saída religiosa" para explicar os acontecimentos de sua vida. Embora Cabanes tenha utilizado este termo para referir-se à saída próxima à teologia da libertação, parece-me que é possível fazer um paralelo às outras "formas de religião" como ordenamento do mundo cotidiano. Uma religiosidade que guia suas convicções mais íntimas e flerta com uma individualidade e uma meritocracia do ser. De certo, como apontou o autor, a saída religiosa é um dos caminhos sociais mais frequentes utilizados como estratégia de vida. É interessante notar que, neste caso, a "saída religiosa" está mais em confluência com códigos morais que preconizam o empreendimento de si, do que com a teologia da libertação (que está mais próxima de uma perspectiva de direitos).

No tocante ao mundo do trabalho, nota-se que tanto o homem quanto a mulher trabalham, embora a obrigatoriedade parece ser do homem - que coloca dinheiro em casa. Karol, cuja a família é de origem camponesa, se dedicou a trabalhos tanto ligados ao campo - como a colheita de frutas -, como serviços derivados da esfera doméstica faxineira; embora também destaque seus bicos de vendedora e ajudante de gesseiro. Roberto parece ter uma trajetória de trabalho tipicamente masculino, associado à força física e proteção: gesseiro, metalúrgico, transportador e, por fim, cobrador de ônibus. Também é interessante notar como Roberto aciona o homem protetor ao enfatizar que largou um trabalho que ficava longe de casa para poder cuidar e proteger a mulher e a filha, revelando sua função de protetor ${ }^{21}$ acima do de provedor.

\footnotetext{
${ }^{21}$ Sobre essa questão ver Fonseca (2004).
} 


\section{A Família, a casa e a cidade: formas de organização da vida e a (re)produção do espaço urbano}

As narrativas familiares apresentadas tiveram a finalidade de discutir o uso e as apropriações do espaço urbano pelo cotidiano social, colocando em diálogo com o PMCMV e as conjunturas socioeconômicas. Os inconvenientes, o planejado, as formas de organização e rearranjos familiares, a migração, a urbanização e a industrialização, as estratégias para lidar com as mudanças socioeconômicas, a pobreza, o desemprego, e a falta de moradia são percursos e ações que moldam as sociabilidades, as relações de gênero e raça, e os próprios espaços urbanos. Em outras palavras, as estratégias familiares na (sobre)vivência do cotidiano.

A entrevista de Maria apresentou uma mulher chefe de família que apontou as políticas sociais - o Programa Bolsa Família e o PMCMV - como benéficas em sua trajetória de moradia e de vida. Por outro lado, ela se manteve em uma relação de matrimônio desgastante, na qual o marido usufruía do lar sem colaborar com o mesmo. Observamos aqui o papel de gênero familiar. Maria constituiu uma família monoparental e foi assumindo todas as responsabilidades dentro e fora da casa.

Maria parece se aproximar da cosmovisão e das formas de organização da vida social que Cabanes (2011) chamou de "saída sócio-festiva". A chefe de família aproveita as oportunidades oferecidas pelo mundo social sem questioná-las, o que, segundo o autor, não as impede de julgá-las ou dizer o que deveria ou não deveria ser. De modo geral, é a luta para superar as dificuldades da vida e o acaso das possibilidades de transformação do mundo social que vão guiando as suas ações. Embora existisse uma participação dos programas de assistência e combate à pobreza nas trajetórias de Maria, aparentemente ela não concebe as políticas sociais enquanto direito, mas sim enquanto ajuda. Há uma exaltação, mesmo que discreta, da individualidade, da luta, de abraçar as oportunidades e fazer o melhor com isso, mas, por outro lado, não há uma crença de que as estruturas sociais e políticas vão melhorar, e nem uma vontade de mudá-las.

Um momento pode escapar um pouco desta saída sócio-festiva: a luta de Maria pela pensão alimentícia de seu ex-marido. Parece-me que ela buscava acessar mecanismos de justiça maiores, reconhecendo que aquilo era seu por direito e que a luta de uma vida toda sofrida estava ali representada naquela conquista, e ninguém poderia 
tirar-lhe. Talvez representasse fazer justiça depois de sofrer dez anos com o descaso do marido irresponsável. Parece-nos que acesso ao "direito" tem se dado por mecanismos de judicialização e não por demandas coletivas articuladas.

De modo geral, as formas de organização familiar parecem compreender o trabalho como saída ao mesmo tempo em que não acreditam nos mecanismos de direitos sociais oriundos do Estado. Ainda é importante observar que os papéis sociais de gênero são claros: a mulher chefia e gerencia a família. $O$ que se coloca em questão é: o que manteria ela atrelada ao marido que parece não se esforçar para a manutenção do grupo social? Partindo da concepção de Sarti (1996, 2004), parece-nos fundamental compreender o matrimônio como um arranjo tradicional, sempre existindo barreiras (simbólicas e morais) ao seu fim, o qual, no caso de Maria, perdurou até o marido colocar um ponto final.

No caso do casal Roberto e Karol, os programas de assistências também representaram um momento importante em suas vidas: a conquista da casa própria, o abandono da instabilidade de moradia. Por outro lado, o desemprego marcado pelo momento de crise econômica e pela flexibilização trabalhista pesaram mais. A casa própria começou a se tornar um fardo devido à obrigatoriedade da fixação em um lugar. A busca por emprego e as estratégias de sobrevivência começam a se delimitar a um espaço físico, e a única fonte de "renda", o Bolsa Família, tornou-se quase insignificante para o casal.

A saída para ler as transformações pelas quais a família e o mundo passam, e para "reconfortar os corações", nas palavras de Roberto, está intimamente ligada com a religião e a moral cristã, que são acionadas a todo momento ao longo da entrevista. Como Karol frisa, "foi tudo projeto de Deus em nossa vida". E quando as coisas começam a dar errado, ela mesma questiona e depois dá a resposta: "às vezes eu até brigo com Deus e falo: 'por que tanta gente ruim, com tanta maldade no coração, conquista muitas coisas? E as pessoas que são mais simples, que tem mais amor, por que?' (...) Eu acho que através do sofrimento que a gente vai aprendendo cada vez mais, né?!".

É dessa maneira que o casal vai buscando sobreviver ao desemprego, à crise, à fome e à falta de dinheiro, se apegando à fé, aos planos que Deus fez para eles, e ao sofrimento que dignifica as ações humanas e que vai recompensá-los. As formas de organização familiar estão relacionadas com a religião, e não somente com as condições 
materiais, embora as duas se misturem com frequência ao longo da narrativa. É interessante notar como a moral cristã do casal dá substrato para os significados e arranjos de suas vidas.

De modo geral, pareceu-me que o papel da casa própria tem uma relação direta com os arranjos de gênero. Em primeiro, Maria consegue se estabilizar minimamente, não dependendo mais do marido para pagar o aluguel ou negociar situações de despejo, e constituindo uma família monoparental a partir de sua estabilização. Hoje se sente mais tranquila e não vê a necessidade de arrumar um novo companheiro. Para o casal Roberto e Karol, onde os papéis sociais de gênero são mais claros, no sentido de representarem os papéis sociais de gênero "tradicionais", o marido tem (ou procura ter) o trabalho principal, a mulher faz bicos para complementar a renda e cuida da casa e da filha.

São estes processos e as formas de organização familiar que, quando colocados em relação ao mundo externo, ao mundo do trabalho, da escola, do lazer, etc, têm potencial de ressignificação do espaço urbano. Em outras palavras, os arranjos familiares têm impacto no mundo (no caso aqui, o espaço urbano), e o mundo tem impacto nas formas de organização familiar. Nos casos apresentados, destacamos a busca pelo trabalho, as trajetórias urbanas e, principalmente, a busca por moradia e os arranjos feitos, as casas alugadas, cedidas, divididas, os terrenos comprados e parcelados, em momentos distintos da vida e da economia, que dialogam com a produção do espaço urbano. Assim, vale pontuar algumas considerações sobre a relação das famílias com o processo de urbanização de São Carlos.

No contexto geral das entrevistas, observamos que as duas famílias são migrantes do final do século XX, entre 1970 e 1980, momento no qual São Carlos teve um novo impulso industrial e agrícola, colaborando para a expansão urbana e o processo de periferização (Lima, 2008). Como foi apontando, as famílias de origem popular se instalaram em bairros historicamente pertencentes à classe pobre, de trabalhadores semiespecializados ou operários. Bairros estes com baixa infraestrutura. O processo de autoconstrução, estratégica clássica durante o processo de urbanização brasileira, marca parte das trajetórias apresentadas.

Uma diferença significativa entre o processo de urbanização da última metade do século XX e os atuais loteamentos periféricos, em São Carlos, são as condições de infraestrutura urbana. Como demonstrado por Lima (2008), depois de 1929, o 
desenvolvimento do uso e ocupação do solo urbano foi marcado pela forte ação de especuladores imobiliários e por loteamentos voltados às classes populares onde não havia o mínimo de infraestrutura urbana, como rede de água e esgoto, energia elétrica ou asfalto. Por outro lado, apesar de manter práticas de segregação urbana, espraiamento urbano e precariedade de equipamentos coletivos, o PMCMV Faixa 1, obrigatoriamente, equipa seus bairros com rede de energia elétrica, de água e esgoto, aquecimento solar individual (opcional) e ruas asfaltadas e iluminadas, diferenciando-se do padrão de expansão destes loteamentos. Esta mesma população que marcou e impulsionou o processo de urbanização e industrialização, transitando entre os bairros precários, periféricos, frutos da autoconstrução, constitui parte da demanda atendida pelo PMCMV- Faixa 1 - no caso, o Jd. Zaváglia.

Sobre a condição socioespacial do bairro, de modo geral, embora algumas estratégias de deslocamento urbano possam variar de família para família, constatou-se um processo de difícil mobilidade para as famílias de baixa renda residentes no Jd. Zaváglia, devido à distância física e às barreiras sociais e econômicas. Soma-se a isso a precariedade das linhas de transporte público. Também foram unânimes as considerações sobre a precariedade dos equipamentos coletivos dentro do bairro. É interessante frisar como as condições objetivas e sociais dialogam diretamente com as estratégias familiares do cotidiano, e como estas estratégias dialogam com a ocupação, com o uso e a expansão urbana da cidade.

\section{Notas finais}

Migração, rede familiar, trabalho, projetos pessoais e familiares, religião, políticas sociais, terceiro setor, arranjos de gênero, dentre tantas outras coisas, são categorias que perpassam a produção do espaço urbano, acomodando distintas lógicas e racionalidades, de diferentes espaços-tempos e diferentes projetos de vida.

Busquei demonstrar, neste artigo, como as trajetórias familiares em busca de moradia e trabalho se relacionam intimamente com a produção do espaço urbano. Famílias que migram em busca de uma vida melhor, transitam de periferias para periferias, que se utilizam das redes familiares para se locomoverem ou permanecerem, e que acreditam (ou não) terem encerrado suas trajetórias de migração ao conquistarem a casa própria. Notamos como o projeto de migração, tão fundamental nas últimas 
décadas do século XX, continua se constituindo como ferramenta na busca do melhorar de vida.

Nestas andanças, a religião mostra-se como um importante substrato na luta diária, seja por meio de doações materiais no fomento da autoconstrução, seja no apoio por meio da fé ou de previsões divinas. A esfera dos direitos sociais se mescla e se confunde com a esfera da religião e do próprio terceiro setor (no caso, a ONG Céu Azul que alimenta a filha faminta). Como acomodar a honra de colocar o dinheiro em casa com a dependência dos programas sociais da era lulista? O mundo do trabalho (para além da esfera material), leva sujeitos e famílias a migrarem ou a permanecerem, leva o pai de família a cumprir seu papel de provedor ou leva ao abandono do trabalho para o mesmo cumprir seu papel de protetor. Leva os próprios papéis de gênero "clássicos" a se rearranjarem dentro de casa e se rearranjarem também no espaço urbano. A reforma trabalhista de 2017 dialoga diretamente com o espaço urbano, seja na precarização do trabalho terceirizado de Maria ou nas demissões em massa da empresa de ônibus, que impuseram o desejo de migração em Roberto novamente.

Por fim, todas estas lógicas vão (re)produzindo marcas no espaço urbano, simbolicamente ou materialmente. As estratégias familiares em seu cotidiano se mostram intimamente ligadas com a produção do espaço urbano.

\section{REFERÊNCIAS}

AGIER, Michel. Do direito à cidade ao fazer-cidade. O antropólogo, a margem e o centro. MANA 21(3), 2015, p. 483-498.

AMORE, C. S.; SHIMBO, L. Z.; RUFINO, M. B. C. (Orgs.). Minha casa ...e a cidade? Avaliação do programa Minha Casa Minha Vida em seis estados brasileiros. Rio de Janeiro: Letra Capital, 2015.

BARCELL, Bruno Leonardo. A interescalaridade da produção habitacional do Programa Minha Casa Minha Vida em cidades médias: do aumento do consumo 
imobiliário ao aumento das desigualdades socioespaciais. Caderno Prudentino de Geografia, n. 41, v. 4, Jul./Dez. 2019. P. 33-59.

BREDA, Thalles V. Articulações entre a produção do espaço urbano e a gestão do social: agentes e escalas na produção do PMCMV em São Carlos/SP. Dissertação (Mestrado em Sociologia) Universidade Federal de São Carlos, São Carlos/SP, 296f, 2018

CABANES, Robert. Proletários em meio à tormenta neoliberal. In: CABANES, R.; et al. (Org.). Saídas de emergência: ganhar/perder a vida na periferia de São Paulo. Tradução de Ferrone; C. S. Rizek. São Paulo: Boitempo, 2011.

CARLOS, Ana F. A. Da "organização" à "produção" do espaço em movimento do pensamento geográfico. In: CARLOS, A. F. A.; SOUZA, M. L.; SPOSITO, M. E. B. (Orgs.). A produção do espaço urbano: agentes e processos, escalas e desafios. São Paulo: Contexto, 2017, p. $53-74$.

COUTO, Marcia T. Estudos de famílias populares urbanas e articulação com gênero. Revista ANTHROPOLÓGICAS, ano 9, vol. 16(1), 2005, p 197 - 216.

DURHAM, Eunice. $A$ caminho da cidade: a vida rural e a migração para São Paulo. São Paulo: Perspectiva, 1978.

FAUSTO NETO, Ana Maria. Familia operária e reprodução da força de trabalho. Petrópolis: Vozes, 1982.

FONSECA, Claudia. Família, fofoca e honra. Porto Alegre: Editora da UFRGS, 2004.

GEORGES, Isabel P. H.; CEBALLOS, Marco. Bolsa Familia y la asistencia social en Brasil: de la lucha política a la mercantilización local. In: Caderno CRH. Salvador, v.27, n.72, set./dez, 2014.

GUIMARÃES, Nadya A.; GEORGES, Isabel P. H. A construção social de trajetórias de mando: determinantes de gênero nos percursos ocupacionais. In: Cad. Pagu, n. 32, 2009, p.84-134.

GUIMARAES, Nadya Araujo; GEORGES, Isabel. A construção social de trajetórias de mando: determinantes de gênero nos percursos ocupacionais. IN: Cad. Pagu, nº.32, 2009, p.84-134. 
LEÓN, Magdalena. La identidad se construye en la familia? Isis internacional Ediciones de las mujeres, 20, 1994, p. 29-42.

LIMA, Renata, Priori. Limites da legislação e o (des)controle da expansão urbana: São Carlos (1857 - 1977). São Carlos: EdUFSCar, 2008.

MOTTA, Roberto; SCOTT, Russell Parry. Sobrevivência e fontes de renda: estratégias das famílias de baixa renda no Recife. Recife: Sudene/Massangana,1983.

ORSI, Rafael Alves. A produção do espaço urbano a partir da política habitacional do programa "minha casa minha vida": integração ou fragmentação? In: ORSI, Rafael Alves (Org.). O espaço urbano produzido: atores e desafios, planos e perspectivas. São Paulo: Cultura Acadêmica, 2018.

ORSI, Rafael Alves. Paisagens em movimento: transformações pós-ocupação nos conjuntos habitacionais do Programa Minha Casa Minha Vida. Novos Cadernos NAEA, v. 23 , n. 1, 2020, p. 261-280.

POLI, Mariana N. A Geografia do espaço vivido: Análise do uso social do solo urbano - estudo de caso na cidade de São Carlos, SP. Dissertação (Mestrado em Engenharia Urbana). Universidade Federal de São Carlos, 2004.

RIZEK, Cibele Saliba. Trabalho, moradia e Cidade: Zonas de indiferenciação. In: Revista Brasileira de Ciências Sociais (impresso), v. 27, 2012, p. 41-50.

RUFINO, Maria Beatriz Cruz. Um olhar sobre a produção do PMCMV a partir de eixos analíticos. In: AMORE, C. S.; SHIMBO, L. Z.; RUFINO, M. B. C. (Orgs.). Minha casa...e a cidade? Avaliação do programa Minha Casa Minha Vida em seis estados brasileiros. Rio de Janeiro: Letra Capital, 2015.

SARTI, Cyntia. A família como espelho: um estudo sobre a moral dos pobres. Campinas: Autores Associados, 1996.

SARTI, Cyntia. A família como ordem simbólica. Psicologia USP, vol. 15(3), 2004, p. 11- 28 .

SIQUEIRA, Barbara Vallilo. O atual modelo de produção periférica nas cidades brasileiras: o Programa Minha Casa Minha Vida nos municípios paulistas de São Carlos e São José do Rio Preto. In: VII Seminario Internacional de Investigación en Urbanismo, Barcelona-Montevideo, 2015. Disponível em: https://upcommons.upc.edu/handle/2117/81312. Acessado em jun. 2020. 
Narrativas Urbanas: Acesso à moradia, organização familiar e a (re)produção do espaço urbano

WOORTMANN, Klaas. A família das mulheres. Rio de Janeiro: Tempo Brasileiro. 1987.

Recebido: 24/03/2020

Aprovado: 04/09/2020 